\title{
The Administrative Structure of Achaemenid and Seleucid Empires in Observing Civil Rights
}

\author{
Mehrnaz Behroozi and Leila Kochaki Kia
}

\begin{abstract}
The civil right is a mixture of responsibilities and duties on the shoulders of the citizens towards each other, their city and government. it also applies to the rights which must be exercised by the ruling government. However, the new debate regarding the importance of these rights among governments in the past and the amount of the value that was put on them by the governors needs to be considered with greater care. Iran during its history was invaded many times hence being a host for diverse cultures of its invaders. This country had had many Iranian and foreigner governments ruling over it each of which had a great effect on the structure of the government as well as achieving justice to ensure the continuity of upholding the law and civil rights. The objective of this research is to consider the civil rights and its variables during Achaemenian and Seleucid Empires and tries to answer this question that: Given the civil rights of the citizens in old Iran time, were the administrative structure of the Achaemenid and Seleucid Empires acted effectively in terms of civil rights of the citizens? To answer this question, we adopted a descriptive-analytic as well as documentation method by collecting information from library which led to these answers that: 1. In Achaemenian time, reign was regard as divine and observing civil rights and obtaining justice was a divine duty 2 . In the meantime, sharing duties and assigning responsibilities in the Achaemenid structure and supervising each authority and governor resulted in achieving a good level of civil rights for their people. On the other hand, during Seleucid Empire Egyptian cities had its special and specific rights unlike the Iranian cities and any court case regarding Iranian and Egyptians was handled in Egyptian courts based on their own laws and judiciary system. 3. In no documents found about Achaemenid time there was no reference with regard to slavery; conversely during Seleucid time slavery was to an extent that many buildings and monuments were built using slaves; in fact, slavery was one of the main parts of citizenship in Egyptian law. So, we can safely assume that the structure of the government is essential in the continuity of civil rights.
\end{abstract}

Index Terms-Achaemenian, seleucid, civil rights, law, justice, government.

\section{INTRODUCTION}

Civil Rights is regarded as one of the concepts of the new Law and justice system since it plays an important role in maintaining discipline, safety and improvement of the society. This concept is attracted by many politicians nowadays. Civil Rights can be defined as the rights of citizenship, personal, political, civic, social, cultural and economic rights that are granted to citizens as to their habituating a certain geographical territory or their relation with the ruling government [1]. Theorists of civil rights know the most important component of citizens, to benefit from three

Manuscript received August 25, 2016; revised March 1, 2017.

The authors are with the central branch Azad university, Tehran, Iran (e-mail: Mehrnaz_behroozi@yahoo.com,Leyla_kia@yahoo.com). categories: civil, political and social rights [2]. As a result discussing this issue and the essence of it is of lofty value.

Achaemenid Dynasty was the first empire that managed to unite the Eastern nations, in other words the contemporary civilized nation, at that time. This unification could not be achieved without mutual respect and placing value for law, traditions and the cultures of citizens at that time. Respecting regulations and laws and enforcing them seriously was a beginning to treasuring civil rights in old Iran.

However, Seleucids in order to dominate Iran implemented major changes in the political, economic and cultural structures. Backed up by Egyptian and Macedonian citizens in Iran, they reshaped the social-cultural face of the dominated Iran at that time. Due to Egyptian nation seeking political and cultural priority during history, it was obvious that there was no equality in enforcing laws whatsoever. This was the beginning of the contrasts in paying attention to civil rights. This research will reflect on the influence of these two empires on the civil rights of their time. Due to the fact that the structure of a government is vital to its essence and concepts and if it does not have the quality of being eligible for justice, the people will not enjoy justice as well. As a result, the author used the qualitative -analytic and documentation method to first analyze the justice situation in these two empires' era from the structure of the government and the components of the existence of civil rights at that time.

\section{ACHAEMENID DYNASTY}

\section{A. Administrative Structure}

The main part of the Achaemenid Empire consisted of three councils (Elite, Royal and Military Council) with the king being the top on. The rights and merits for the king rooted back to this belief that regality was considered as a divine blessing granted through Ahura Mazda [3]. So, the legislative, judiciary and executive forces were in his disposal and his will towards anything may lead to enact law in that area [4].

However, there was a council mainly included the rich of tribes and the chieftains where the king referred to in case of emergency and after their approval came to a decision. As a result, since the king had to confer these councils for any final decisions [5] we cannot name Achaemenian Kings as tyrant and autocratic.

After the king, Hezarpat (the prime minister) was the most important person [6]. His area of work was so vast that he had to have many clerks by his side [7].

In order to avoid giving too much power to one person all over the Achaemenid Empire there were different provinces based on administrative and taxation point of view. Each province had a governor general (titled as Khashrapaun/ Xšaçapāvan) worked independently [8] and was assigned by the king, he was usually a part of his family member, local 
governor and sometimes Achaemenid prince or the chiefs of Pars, Mede and rich tribes. This governor was vicegerent in his ruling place; in the area of ruling and supervising his power was so much and related to the king himself [8].

\section{B. Following Rules}

In the Achaemenian time rules and laws fell into two categories: 1. Overall rules regarding the general discipline of the kingdom and administrative, financial and military organizations. 2. local and citizenship laws and regulations

The first type must be obeyed all around the kingdom but the judiciary issues of the dominated countries which had their own traditional laws remained intact and they were treated accordingly [4].This shows great value to justice in a governmental system because when some rules and traditions are exercised by people over time they become part of them and highly valuable to them so changing those rules seems unfair to them. The documents left from Achaemenid era show that how laws and regulations were so important and serious even for the king himself [9]. As a result, Herodotus refers to a single law that requires praise: "For a minor crime even the king cannot kill anyone and so the Persian cannot punish severely their slaves because of a single minor crime, they cannot unleash their rage on them until that crime is so much bigger that what that person did." [10].

\section{Judgment and Trial in Achaemenid Era}

All Achaemenid kings were deeply interested in upholding the law and maintaining justice in the society. Each province had its own magistrate to handle the legal issues among people under the supervision of the governors and the ones who failed to do their job well would face severe punishment [ 10] the punishment for political crimes were set in the capital city by the king or royal magistrates [11]. The king was the only person who could change the verdicts of the magistrates and his own verdict was unchangeable. The story of Tasahpiye, Achaemenid prince, was one example in this regard [12].

In the judicial issues the king tended to ask an experienced old oracle, although he had all the power to so himself [10]. After that there was the Divine or Elite Court consisted of eight judges, then there were local, regional Courts all around the country. The laws were enacted by druids and for a long time they had the responsibility for handling legal issues but in the more recent time there were some men and women taking up the responsibility apart from druids [13].

\section{Occupation and Social Welfare}

In the years 1933-1934 A.D during Persepolis excavations, the royal capita of Pars, thousands of clay tablets were found which had Elamite cuneiform writings on them. These writings were mostly about the main core of the regal system, occupational situations, workers' wages and conditions in that era. These show how at that time Iranian valued justice and welfare for their own people while most civilized nations at that time still had slavery and exploitation of human beings.

-At that time the workers' wage mostly paid through goods and the main measurement unit was "BAR" based on Oat. The minimum wage was 3 bar of oat which was the minimum amount a low experienced teenage worker would get [7].

-All the workers who had the minimum ratio had extra income under diverse titles and events, like every two months a bonus was given to them, too. Also, we must add to this bonus a special ratio called royal ratio [7].

-Workers' wages and their ratio at that time was based on their skill, value of their work, the amount of time it consumed and their age [14].

-Women workers were also had different jobs and in cases for doing the same job as men got the same wage.

-Pregnant women during delivery had more ratio as a bonus for five months but it was based on the sex of the child [15].

-Diverse governmental helps should also be added to the workers' wage which included special help to workers whose job was so heavy [15].

-The ceremonial chief which was the top rank in administrative and executive system at that time was responsible to handle any contradictory issues regarding internal problems among organizations and asking the accountants and chieftains to go strictly by their work laws and regulations [5].

\section{E. Treating other Nations}

Cypress based on maintaining an affability policy based on equality let other nations and their people to stay on their traditional religion even after victory over them and praised their traditions, cultures as well as their rituals. He also returned what other tyrant nations got from them [16]. Cypress returned five thousand four hundred gold and silver vases taken from the holy temple to Jews so as to return them to Jerusalem [17]. Based on the Behistun epigraph Darius after conquering a country or suppressing revolts, offered mercy and treated the remaining people kindly and if they accepted his friendship offer, he would even help them [18]. The epigraphs remained from this king show these clearly [19]. Darius also helped rebuilding the Jewish synagogues which were destroyed by Bakht-al nosar /Nebuchadnezzar [20].

\section{SELEUCID DYNASTY}

Before entering the main discussion, it is essential to explain two important points:

1. In Athens which was the most civilized city of Greece at that time, based on the laws in $6^{\text {th }}$ century which was enacted officially at the end of $7^{\text {th }}$ century,

Just special people who had unique features could enjoy citizenship rights one of these features was having a specific amount of wealth which let him buy some native slaves and have them work for him. According to the laws at that time in Athens, natives did not have the right to own anything and just could be a slave who had to do hard labor for their owner [9]. So, all the people in Greece at that time were not allowed to cooperate and take part in most administrative organizations and this led to a big social gap.

2. After the victory of Alexander and coming of Seleucid to power, Macedonian kings got the title of "The Great King" or "King of the Kings"; however, there was a substantial difference that from the Alexander time onward, Seleucid's king called themselves GOD [Theous] [21]. This notion was brought by Alexander from Egypt to Iran which remained among his successors [22]. As a result, maintaining justice was not regarded as one of the divine responsibilities of the government and did not prevent kings to exploit their authorities. 


\section{A. The Structure of the Government}

Greek people after the dominance of Iran, left many old governing methods. The Egyptians got that without Iranian helping them there would be no chance for them to rule over the invaded Iran so they did not change most administrative and royal organizations and let them continue their work as before. Many Iranian princes, chiefs and governors remained on their posts [23].

Macedonians aside from continuing Alexander methods (accepting migrants in order to help economic and military improvements), kept all intact administrative and political structures at their disposal and let them be. They also used the provinces that now Macedonian governors are ruling, turning them into new cities [24].

However, the Greek -Iranian cities besides being granted the self-governing opportunity from the Seleucid kings had limited self-governing merits compared to the main cities. The foreign relationship issues were related to the Seleucid king living in Seleucid, Antioch and Lydia. On the other hand, thepro-king sector were fully aware of the financial and legal issues of the king and were ready to defend them if it was necessary. Other than that, one or more garrisons were present in the city so the cities become fully obedient to the king, the governor of the city was not that much serious or even important [25].

The Seleucid kings were very kind to their allied cities letting them have freedom in their domestic issues even minting coins. They got tax from those cities and gave them large lands, internal affairs were supervised by the local rich [26]. However, cities never got the value and importance of a big city called "Polis" at that time.

Iranian cities needed self-governing system in their vicinity which was governed by the local councils included people who were responsible for everything. Each city had its own troops, elite laws and worshiping method on the framework of the civil rights along with other structures they taught Greece traditions to people [26].

These cities were built in the Easter, Western and Central parts of Iran. They were cultural and economic bases of Seleucid. Citizens of these cities had the social rights and facilities but not in an equal basis. The existence of cultural as well as political superiority in Greek people at that time to others especially Iranians who cooperate with the city governors was very obvious. The structure of the big cities called Polis required Greek residents or Greek-Macedonian ones not foreigners, slaves' non-European migrants. In fact, Iranians had a special condition apart from others at that time; they had even their own party [27].

\section{B. Economic and Trading System}

Alexander used the great treasure of the Achaemenian Empire which were left unused and useless he got the minting right from the city governors called "Satrap" and gave it to just king and the central government. He modified the currency by changing the Achaemenian money to Greek one called Attica causing a unified easier to use currency system [28]. As a result of that, the financial system became organized, the basics of statistics were established, rules were set for goods like salt-perfumes -trading and navigating over large rivers. The abundance of the raw material enhanced the industry in Iran and most importantly international trading flourished [29].

\section{Judgment and Judiciary System}

During Seleucid era, enforcing and observing the law were different among Iranian and Greek people. Greek people in Shush/Susa had laws regarding liberating slaves in Greek language. These laws were written and hanged by the walls of Nanayana Temple [26].

Legal cases and arguments among Iranian and Greek people were handled by Greek judges based on Greece civil laws. So, many natives became aware of the Greek laws; even they accepted and used them in their relations among themselves [13]. However, in rural areas of Iran people were still loyal to their own traditional laws and values and any legal case was handled in local civic councils [13].

\section{Treating other Nations}

Alexander before attacking and invading Iran destroyed the city of Thebai/ Thebes which resisted him and took its people as slaves and set Persepolis, a significant royal place for decision making, he also slaughtered the people in Soor/ Tyre city near Mediterranean Sea. The big cities, which were built all over the invaded areas, were built by slaves and war prisoners [28].

Antiochus IV forced the Jewish areas to be Hellenic. He ordered to abrogate all religious traditions of Jews and all religious scriptures had to be given to him. He also forbade circumcision and instead of Jewish Temples Hellenic ones like Zeus had to be built. He ordered an irritant slaughter of Jews. Seleucid killed many men and took women and children and sold them as slaves. They destroyed all the walls of Jerusalem [30].

TABLE I: THE CIVIL RIGHTS IN ACHAEMENIAN AND SELEUCID ERA

\begin{tabular}{|c|c|c|c|}
\hline No & Background & Achaemenian & Seleucids \\
\hline 1 & $\begin{array}{l}\text { Enforcing civil } \\
\text { rights and } \\
\text { justice in } \\
\text { governing }\end{array}$ & $\begin{array}{l}\text { Regality is a divine } \\
\text { blessing, so } \\
\text { maintaining justice is a } \\
\text { religious duty. }\end{array}$ & $\begin{array}{l}\text { Kings knew themselves } \\
\text { as God. So, there were } \\
\text { no forces on them to be } \\
\text { bound to the justice. }\end{array}$ \\
\hline 2 & $\begin{array}{l}\text { Maintaining the } \\
\text { civil rights of } \\
\text { the invaded } \\
\text { cities }\end{array}$ & $\begin{array}{l}\text { Respect other nations' } \\
\text { cultures and traditions. }\end{array}$ & $\begin{array}{l}\text { At first they paid } \\
\text { attention to the } \\
\text { traditions of the beaten } \\
\text { nations but afterwards } \\
\text { ignored them. }\end{array}$ \\
\hline 3 & $\begin{array}{l}\text { Tax collecting } \\
\text { methods based } \\
\text { on civil rights } \\
\text { doctrine }\end{array}$ & $\begin{array}{l}\text { By modifying taxation } \\
\text { system, there were } \\
\text { justices in collecting } \\
\text { them. Governors were } \\
\text { prevented and } \\
\text { forbidden to exploit } \\
\text { their situation in } \\
\text { increasing tax. }\end{array}$ & $\begin{array}{l}\text { Most taxes were paid } \\
\text { by farmers besides } \\
\text { paying another type of } \\
\text { tax called "Royal Tax". }\end{array}$ \\
\hline 4 & $\begin{array}{l}\text { Civil rights for } \\
\text { slaves and war } \\
\text { prisoners }\end{array}$ & $\begin{array}{l}\text { Jews were allowed to } \\
\text { get back to invaded } \\
\text { cities and prisoners } \\
\text { were not tortured. }\end{array}$ & $\begin{array}{l}\text { Slaves and prisoners } \\
\text { were forced to work } \\
\text { during building sites } \\
\text { without being paid or } \\
\text { given any rights. }\end{array}$ \\
\hline 5 & $\begin{array}{l}\text { Administrative } \\
\text { and judiciary } \\
\text { issues }\end{array}$ & $\begin{array}{l}\text { Judiciary systems of all } \\
\text { provinces in Iran were } \\
\text { based on their own } \\
\text { dominant laws and } \\
\text { traditions and judges } \\
\text { were supervised by the } \\
\text { governors. }\end{array}$ & $\begin{array}{l}\text { Legal cases and } \\
\text { arguments between } \\
\text { Iranian and Greek } \\
\text { people were handled by } \\
\text { Greek judges based on } \\
\text { Greek laws and civil } \\
\text { rights. }\end{array}$ \\
\hline
\end{tabular}

\section{CONCLUSION}

Based on what has been said till now, we can safely assume that the Governmental structure undoubtedly has a great effect on keeping justice and upholding Civil Rights. 
The existence of positive interaction between the Achaemenid governors and maintaining justice can be regarded as one of the most distinctive features regarding civil rights at that time. Regality was considered as a divine blessing granted by Ahura Mazda in a case that maintaining justice was regarded as a religious duty and prevented any exploitation from kings. On the other hand, Seleucids called themselves God and had no concerns in keeping justice due to the fact that it was not their religious duty.

Assigning duties and dividing power during Achaemenid Era and the strict supervision on governors and civil workers for collecting tax and treating people ensured maximum justice and welfare for people that led to a system free of corruption. It also bolstered political and judicial justice in the society. On the other hand, in Seleucid era each city, called Polis, had its own authorities; in Iranian cities regardless of self-governing international issues were settled directly by the Seleucid king. Legal and financial cases were directly dealt with by the king or people whom he appointed called "Epistat". Arguments between Iranian and Greek people were handled in Greek trials by Greek judges based on Greek laws so it means that Iranian cities and their citizens had no rights at all.

In old clay epigraphs that were excavated from Persepolis many stunning cases were found showing equality, justice, bonus system for workers, maternity rights, monthly payment bonus, hard labor bonus, using skilled foreigner workers and so forth during Achaemenian era. All the people whether Iranian or foreigner got their own salary. In none of the documents we could find any sign of slavery and selling slaves; however, during Seleucid time many cities were built by slaves and war prisoners (POWs). They levied heavy taxes on farmers and also got Royal taxes too, in other words farmers paid tax twice.

\section{REFERENCES}

[1] R. Biranvand, Officers Responsible in Citizenship Law, Ghom: Ghaza, 1393, p. 15.

[2] N. Katuziyan, Philosophy of Law, Tehran: Joint Stock Company publication, 1377, p. 381.

[3] M. Ehtesham, Iran in Hakhamaneshian Dynasty Era, $1^{\text {st }}$ ed. Tehran: Pocket Book Publishing, pp. 42-44.

[4] A. A. Ahmadi, The Judiciary Act in the Achaemenid Empire, Tehran: Culture and Art, 1346, pp. 42, 57-58.

[5] P. Briant, Achaemenid Empire, translated by: N. Forughan, Tehran: Ghatreh, 1381, pp. 91, 734-735.

[6] S. Bayani, Ancient Persia History, Tehran: Samt, 1381, p. 181

[7] H. M. Kokh, Es kündet Dareios der König, translated by: P. Rajabi, $11^{\text {th }}$ ed. Tehran: Karang, 1385, pp. 42, 61, 62 .

[8] A.H. Zarrinkub, Days Iran's Past, Tehran: Sokhan, 1375, p. 79.

[9] A.T. Olmstead, The History of Persian Empire, translated by: M. Moghadam, $7^{\text {th }}$ ed. Tehran: Amir Kabir, 1386, pp. 175, 284.

[10] Herodotus, The History of Herodotus, translated by: Mortezathaghebfar, Tehran: Asatir, 1389, pp. 137, 1-2, 3.

[11] A. A. Rezaie, Ten Thousand Years of Iran History, $7^{\text {th }}$ ed. Tehran: Eghbal, 1375, pp. 245-255.

[12] W. Hinz, Darius and the Persians, translated by: P. Rajabi, Tehran: Mahi, 1388, p. 316.

[13] M. Ravandi, Process of the Law and Judiciary in Iran, Babol: cheshme and Ketbsaraye Babol, 1368, pp. 10, 13, 115 .

[14] E.A. Grantoski, and others, History of ancient Persia to this day, translated by: K. Keshavarzi, $2^{\text {nd }}$ ed. Tehran: Morvarid, 1386, p. 88.

[15] R.T. Hallock, Persepolis Fortification Tablets, Chicago: University Chicago, 1969, pp. 344, 314.

[16] P. Grimal, The Myth of Babel in Ancient Persia, translated by: M. Azad Tehrani, Tehran: Amuzesh Enghelabe Islami, 1384, p. 126.

[17] Ahde Atiq, (The Jerusalem Bible) Torah or law books, Tehran: Hermes, 1349, p.126.
[18] R. G. Kent, Old Persian (Grammar, Texts, Lexicon), American Oriental Society: New Hawn, 1961, p. 140.

[19] A. Kasravi, Bistoon: Inscriptions of Aryan, Tehran: e-book, 1383, p. 7.

[20] A. H. Zarrinkub, A People's History of Iran, Tehran: Amir Kabir, 1364, p. 150

[21] M. Rostovtzeff, The Social and Economic of the Hellenistic Word, Oxford: Clarendon Press, 1941, p. 5.

[22] V.V. Bartold, Stated Historical Geography of Iran, translated by: T. Ghaderi, Tehran: Fekre Emroz, 1358, p. 25.

[23] R. Ghrishman, Iran is Beginning to Islam, translated by: M. Moein, $19^{\text {th }}$ ed. Tehran: Elmi-Farhangi, 1388, p. 255.

[24] M. Boyce, History of Iran (After Damned Alexander), translated by: H. Sanati Zadeh, Tehran: Toos, 1375, p. 108.

[25] I. M. Diakonoff, Parthian, translated by: K. Keshavarz, Tehran: Andishe, 1352, p. 24.

[26] E. G. Boyle, From the Seleucids until the Collapse of the SASSANID, translated by: H. Anooshe, Tehran: Amir Kabir, 1366, third volume, pp. 109, 398, 114.

[27] O. Klima, History of Mazdakian Movement in Iran, translated by: J. Fekr Yar Shad, Tehran: Toos, 1356, p. 43.

[28] I. M. Diakonoff, History of The Ancient World, translated by: S Ansari and others, Tehran: Andishe, 1351, Vol. 1, pp. 7, 8,

[29] N. Mirsaeedi, Seleucid and Parthian, Tehran: Ghoghnus, 1378, pp. 40-41.

[30] A. Khodadadiyan, History of Ancient Iran (Seleucids), Tehran: Nashr Behdid, 1378, pp. 41-106.

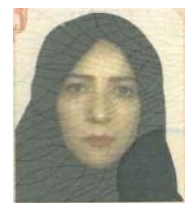

Mehrnaz Behroozi was born in Kermanshah in Iran, in 1964. The author's educational background is type of degree: $\mathrm{PhD}$, in field history and civilization, Azad University of Science and Research, Tehran, Iran, 2002 degree was earned.

She taught at various universities since 1372 and she collaborates with academic centers such as the Great Islamic Encyclopedia, Medical Encyclopedia of Islam and Iran. Moreover, she is a council member of the academic literature review Institute for Humanities and Cultural Studies. In addition, Director of the Department of History, Outstanding Professor of Faculty of Literature from Tehran Markaz Azad University in 1390, Author's notes Training, Taught specialized courses in undergraduate, postgraduate and $\mathrm{PhD}$ in fields of history and the history and civilization and ... The current job is Islamic Azad University Central Tehran Branch; previous positions: Taught at the University of Mashhad, University Rey, and University of Alzahra. Information concerning previous publications: 1The history of political, relations between Elam and Assyria (Germany: Lambert, 2013). 2- A study on Bbuddhism in the Parthian Era in Iran (America: The journal of American Science ISSN (1545-1003), 2013). 3 Balkh (Tehran: Great Islamic Encyclopedia, 1381).Current and previous research interests is history and civilization.

Dr. Behroozi is Designer of Exam Questions Islamic Azad University, The referee books and scientific- Research papers.

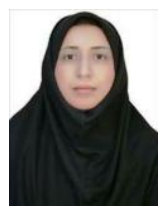

Leila Kochaki Kia was born in Chalous in Iran, in 1976. she received her master degree, from Azad university of Science and Research, Tehran, Iran, 2002 and she is in field history of Iran.

She is director of the Institute of Cultural Research climate seven of wisdom. Moreover, she was co-author at the Institute for Iranian Contemporary Historical Studies. In addition, she taught history and geography in secondary school for two years. The current job is writer and director of the Institute of Cultural Research climate seven of wisdom in Chalous; Information concerning previous publications: The role of Mithraism in the formation and structure of politics and monarchism in Ancient Iran (Iran: MSRT, 2011). Aspects of intellectual influence and Hellenism in politics and monarchism in Ancient Iran (Iran: MSRT, 2011). Relation between year and goods in Persepolis clay tablets (Iran: The first International Conference on Linguistics, 1387/2007) Current and previous research interests is study of women, ancient history as Achaemenid and Mythology.

Ms. Kochaki Kia is an independent person. 